\title{
Reasons of Pedagogical Formation Education Certificate Program Students Taking This Education: Comparison of Different Departments
}

\author{
Rezan Yilmaz", M. Handan Güneş \\ Department of Mathematics and Science Education, Faculty of Education, Ondokuz Mayıs University, Samsun, Turkey
}

Copyright $(2017$ by authors, all rights reserved. Authors agree that this article remains permanently open access under the terms of the Creative Commons Attribution License 4.0 International License

\begin{abstract}
With the influence of social, economic and political change, the education system has undergone many changes in various periods, which in turn has affected training of teachers. With the recent change in the implementation of the Pedagogical Formation Education Certificate Program in Turkey, a decision is being made whether the students or graduates who meet the requirements can receive pedagogical formation training, regardless of faculty positions. Considering that the training of qualified teachers is possible with the participation of those who want to perform this profession consciously, it is thought that the reason why the teacher candidates prefer the teaching profession is very important. This study, aiming to reveal the reasons for the education of pedagogical candidates trained in the pedagogical formation of this program, is a qualitative research conducted with 243 participants from eight different fields, employed and unemployed, students and non-students, who are studying at the faculty of education at a state university. The results of the analysis of the data obtained in written form asking the participants for their reasons to take pedagogical formation education and to elaborate their thoughts in detail are in general anxiety for job finding, career making and self-improvement, desire to perform teaching profession and necessity. Participants have indicated that their desire to perform teaching profession is based on their desire to perform a profession that they dream of, desire to gain an additional advantage, desire to meet the need for the required documentation, and thinking that professional conditions are suitable. In addition, it is noteworthy that the thoughts of the teacher candidates from different fields differed in this context.
\end{abstract}

Keywords Teacher Education, Pedagogical Formation Education Certificate Program (PFESP), Choice of Profession

\section{Introduction}

It is generally accepted that it is an inevitable necessity to train qualified individuals who can adapt to the change process in today's world where fast developments are experienced in each field. The profession of teaching is at the forefront considering that the task of training qualified individuals at this point belongs to the education system. In this context, since the efficiency of the education system is directly proportional to the training of the human power in the desired quality, profession of teaching is considered as one of the most important parts of the education system [1, 2].

The profession is a collection of activities based on knowledge and skills, performed by individuals to earn their living, of which the rules are defined by the society and obtained by certain education [3]. A person gains an identity through the profession, respected and forms a relationship with others, earns a place in the society and have a sense of usefulness [4]. One of the most important facts that naturally shape the life of an individual is the profession of preference [5]. The profession of Teacher is defined in the article 43 of the National Education Basic Law numbered 1739 as "a specialization profession that takes on the task of government's education, training and related administrative duties" [6].

Teaching is known to be a profession that requires cognitive field competencies such as knowledge and skills, as well as affective field competences such as attitude and behavior. Therefore, it is necessary for teacher candidates to acquire the values and attitudes related to the profession as much as knowledge [7]. A teacher is a person who constantly interacts with the student, carries out the educational program, directs the teaching, and evaluates both the student and the education. Therefore, the qualifications of the teacher have a great influence on the education process [8].

Teacher qualifications were determined by Higher Education Council (YÖK) as competencies related to subject 
area and field education, competencies related to learning-teaching process, competencies related to monitoring, evaluation and recording of learning process of students, and other occupational competencies [9]. Also by MEB (Ministry of National Education); personal and professional values-professional development, student recognition, teaching and learning process, learning-development monitoring and evaluation, school-parent and community relations, program and content knowledge [10]. Although these qualifications are necessary to sustain the teaching profession, they are not enough. In addition to fulfilling these conditions, it is necessary for teachers to be able to do their profession with love and devotion. Teaching is a profession that requires love and devotion. Because it is imperative that a teacher who works with people who are biological, psychological and socio-cultural beings likes people, is self-sacrificing, tolerant and patient [11]. As a matter of fact, Gazi Mustafa Kemal Atatürk who is the founder of Republic of Turkey expressed the responsibilities of the teachers at the Congress of Teachers Union in 1924 with the following words: "Teachers; You will train the self-sacrificing teachers and educators of the new generation of The Republic, the new generation will be your work. The value of the work will be proportional to the degree of your skill and sacrifice. The Republic wants a mentally, intelligently, technically and physically strong and high-personality guards. It is in your hands to train the new generation with these features and talents."

In the selection of the teaching profession, the expectations of the individual about the teaching profession, the outlook on the profession and the values of the teaching profession are important [12]. As a matter of fact, being employed as soon as possible is one of the main priorities in career selection [13]. Unfortunately, this brings the question of whether variables such as personality, attention, talent, which are required for individuals to maintain their profession in a satisfactory manner throughout life, are considered. Those who choose the teaching profession are expected to be sufficiently sensitive to the people they are to serve. This sensitivity is related to personal characteristics. Sensitivity levels of those who choose this profession also significantly affect their mental health. Because the profession is an occupation maintained not only for fulfilling the economic needs but also to provide psycho-social development and satisfaction. Some unfavorable conditions such as burnout syndrome and stress reactions can be observed in individuals who cannot provide occupational satisfaction [14].

The studies conducted abroad on teaching profession in general seem to focus on the expectations and perceptions regarding the teaching profession and on the reasons for choosing and leaving the teaching profession [15-19].

There have been many studies conducted on the reasons why the teaching profession is preferred and it is observed that the results of these studies are generally collected in three main titles.

- Altruistic-selfless reasons: Among these reasons are factors such as the teaching profession is regarded as an important and necessary profession for the society, desire to serve the people, desire to be useful to society, serving the country, etc.

- Intrinsic reasons: This category mainly covers the activities involved in teaching profession and the situations related to the nature of teaching. The pleasure obtained from teaching, that is to say loving this profession, loving children, desire to work with children, loving people, thinking that you are talented in this profession, and so on can be given as examples to this.

- Extrinsic reasons: Among these reasons, external factors are mentioned. For example, external factors such as long summer holidays, salaries, status in the community, employment opportunities, social security, and appointment conditions of teachers are included in this group [16, 20-33].

Nowadays, it is a known fact that the factors that usually stand out in the choice of profession are economically based and therefore differentiated from the facts of the individual's occupational preferences [21,25]. At the same time, it is known that in the preference of profession, the talent, interest, system of values and beliefs, family, culture, environment and gender are also influential $[34,35]$. Great similarities between the reasons of general preference of profession and the reasons of preferring teaching profession is also noteworthy [22,29,36-38].

As a matter of fact, Çermik, Doğan and Şahin [37] showed that the utilitarian and extrinsic factors are more dominant compared to intrinsic and selfless factors. They have shown that the reason for preference in the utilitarian category has a change-resistant structure, that candidates do not compromise their personal expectations and interests, and that some participants are beginning to think about the conveniences of teaching in the upcoming military service. Nevertheless, they emphasized that extrinsic factors have largely lost importance in the graduation phase. They also expressed that family and society are more influential than teachers on the profession choice of candidates, almost half of the candidates stating they would not prefer classroom teaching "if they had another chance", and they were experiencing problems in the commitment to the profession. As a result of the study, while utilitarian, extrinsic, intrinsic and selfless factors lie behind the reasons of teacher candidates choosing the profession; it is seen that the utilitarian factors are more resistant to change than the others. At the end of teacher training process, intrinsic and selfless reasons are preferred more; the ratio of those saying "I wouldn't choose the profession again" (especially among the males) gives the impression that the perception of "female profession" is widespread [37].

When we look at the history of the Republic, the schools that were opened under the name of Higher Teacher School started operating from 1924 to educate teachers. In the same period, the teacher need of secondary schools was tried to be met from the Gazi Secondary Techer School which was founded in Konya in 1926 and moved to Ankara in 1927. With the closure of the Higher Village Institutes established 
in 1942, the authorities of this institution were transferred to the Gazi Teacher School, and teacher schools called Education Institute was established in 1946. After 1970, Higher Teachers Schools were closed down and in 1978 the Education Institutes were called Higher Teacher Schools. Until 1982, teachers were educated in teacher schools. However, in 1982, an arrangement was made to train teachers in education faculties. In 1997, those who graduated from education faculties were granted the right to become teachers. Therefore, with the same application, a search was caused on how to gain the required formation for being a teacher for those who are not YÖK faculty of education faculty graduates. This situation has been tried to be solved with the commencing of the master program without thesis in 1998-1999 academic year. In 2010, with a decision taken by YÖK, "master without thesis" program was abolished and instead "Pedagogical Formation Education Certificate Program (PFESP)" was introduced. With this new practice, student or students of departments of all faculties and departments that meet the post-graduation requirements have the right to receive pedagogical formation training. Naturally, this practice has both damaged the social status of the teaching profession and turned the teaching profession into an attractive profession with a validity in the job market [39-41].

There are limited number of studies in Turkey that deal with the education of pedagogical formation which is a newly recognized branch in our country. Most of the studies conducted on this subject are related to the attitudes of prospective teachers, who receive formation education, towards the profession of teaching. According to the results obtained in such studies, it has been identified that the attitudes are generally above the intermediate level and that most of the prospective teachers regard themselves to be ready for performing the teaching profession. Furthermore, differences were observed in attitudes of participating prospective teachers towards the teaching profession in terms of age, gender, graduated or current department, and having preferred the faculty of education when entering the university [40, 42-45].

Altınkurt, Yilmaz and Erol [46] discuss that the students of pedagogical formation program possess high level of motivation towards the profession of teaching in their study, which was conducted with the purpose of revealing the motivation levels of the students of pedagogical formation program towards the teaching profession. They have also determined that the education of pedagogical formation positively affects the attitudes of the students towards the teaching profession. Kiraz and Dursun [47] have identified the perceptions of the students of pedagogical formation program towards pedagogical formation education through qualitative interviewing technique. All of the participants who received pedagogical formation education stated that they enrolled in this program in order to receive the certificate of pedagogical formation. Accordingly, some of the participants found this education adequate and improving; whereas some found this education inadequate and unnecessary. Most of the participants of this study indicated that receiving this education will make it easier to be a teacher and therefore they received the education in order to obtain the certificate of pedagogical formation. Most of the participants believe that their domain knowledge is adequate to perform the teaching profession. Moreover, most of the participants remarked that they are willing to participate in this program to obtain this certificate that is a legal requisite in order to be employed at a state school or in a private school as a permanent staff.

The training of qualified teachers will be possible with the participation of those who want to perform this profession consciously. In this context, the reasons why teacher candidates choose the teaching profession are very important. The aim of the study is to reveal the reasons why the teacher candidates who received the pedagogical formation training in the framework of the teacher training program received this training.

\section{Method}

In this study, case study from qualitative research design was used because presenting the reasons of teacher candidates included in the PFESP within framework of teacher training program aimed in an integrated, deep and flexible way $[48,49]$.

\subsection{Participants}

243 teacher candidates attending PFESP in Ondokuz Mayis University during the second semester of the 2015-2016 academic year have participated in the study. Participants consist of eight departments: mathematics, physics, chemistry, biology, history, sociology, food engineering and midwifery-nursing. Table 1 shows the frequencies and percentages of participants' distribution according to their departments, Table 2 shows the frequencies of distribution of genders according to departments, and Table 3 shows the frequencies of employment and studentship status according to the departments. 
Table 1. Frequency and Percentages of Participants Distribution by Departments

\begin{tabular}{|l|c|c|}
\hline Department & f & \% \\
\hline Mathematics & 47 & 19,341 \\
\hline Midwifery-nursing & 43 & 17,695 \\
\hline History & 41 & 16,872 \\
\hline Biology & 30 & 12,345 \\
\hline Chemistry & 30 & 12,345 \\
\hline Sociology & 30 & 12,345 \\
\hline Food engineering & 13 & 5,349 \\
\hline Physics & 9 & 3,703 \\
\hline Total & 243 & 100 \\
\hline
\end{tabular}

Table 2. Distributions Frequency of Participants by Gender

\begin{tabular}{|l|c|c|c|}
\hline \multirow{2}{*}{ Department } & \multicolumn{2}{|c|}{ Gender } & \multirow{2}{*}{ Total } \\
\cline { 2 - 3 } & Female & Male & \\
\hline Mathematics & 30 & 17 & 47 \\
\hline Midwifery-nursing & 40 & 3 & 43 \\
\hline History & 25 & 16 & 41 \\
\hline Biology & 24 & 6 & 30 \\
\hline Chemistry & 20 & 10 & 30 \\
\hline Sociology & 27 & 3 & 30 \\
\hline Food engineering & 12 & 1 & 13 \\
\hline Physics & 3 & 6 & 9 \\
\hline Total & 181 & 62 & 243 \\
\hline
\end{tabular}

Table 3. Distribution Frequency of Participants by Their Employment and Studentship Status

\begin{tabular}{|l|c|c|c|c|}
\hline \multirow{2}{*}{ Department } & $\begin{array}{c}\text { Employment } \\
\text { Status }\end{array}$ & Student & $\begin{array}{c}\text { non- } \\
\text { Student }\end{array}$ & Total \\
\hline \multirow{3}{*}{ Mathematics } & employed & 6 & 5 & 11 \\
\cline { 2 - 5 } & unemployed & 32 & 4 & 36 \\
\hline \multirow{2}{*}{$\begin{array}{l}\text { Midwifery- } \\
\text { nursing }\end{array}$} & employed & 3 & 30 & 33 \\
\cline { 2 - 5 } History & unemployed & 7 & 3 & 10 \\
\hline \multirow{3}{*}{ Biology } & employed & 3 & 0 & 3 \\
\cline { 2 - 5 } & unemployed & 30 & 8 & 38 \\
\cline { 2 - 5 } Chemistry & employed & 2 & 7 & 9 \\
\cline { 2 - 5 } & unemployed & 14 & 7 & 21 \\
\hline \multirow{3}{*}{ Sociology } & unemployed & 16 & 9 & 25 \\
\cline { 2 - 5 } & employed & 1 & 3 & 4 \\
\hline \multirow{2}{*}{$\begin{array}{l}\text { Food } \\
\text { engineering }\end{array}$} & unemployed & 22 & 4 & 26 \\
\cline { 2 - 5 } & unemployed & 0 & 1 & 1 \\
\hline \multirow{2}{*}{\begin{tabular}{l} 
Physics \\
\cline { 2 - 5 }
\end{tabular}} & employed & 3 & 3 & 6 \\
\cline { 2 - 5 } & unemployed & 2 & 1 & 3 \\
\hline \multirow{2}{*}{ Total } & 153 & 90 & 243 \\
\hline
\end{tabular}

\subsection{Data Collection Tool}

The following open-ended question was asked to reveal the reasons for teacher candidates' taking formation:

"Why did you want to take pedagogical formation? Please describe your thoughts in detail. "

While requesting to answer the question asked, it is emphasized that their explanations are important in terms of developing the program being carried out, the organization of teacher education and revealing the outlook of teaching, their personal information will only be read and stored by the researcher and not used in any other place and purpose, and evaluated by grades. They are also asked not to write their names on the given paper containing the question, in order to allow them to write freely.

\subsection{Data Analysis}

Qualitative research techniques have been used to analyze the written thoughts given by teacher candidates to open-ended questions. All papers were numbered first and then explanations about why they wanted to receive education in each section were consistently compared with the other teacher candidates in order to create common themes $[48,50]$. These common themes were determined were tabulated in consideration of the frequency of repetition. In order to increase the reliability of the study conducted, the categories and common themes that were determined were first examined by two experts separately, and then the disputes between the common themes that were determined to be gathered together were eliminated and a common mutual understanding was established on the categories and themes formed in this way $[48,51]$.

\section{Findings}

The themes and categories that emerged as a result of analyzing the reasons of teacher candidates for taking pedagogical formation were formed on the basis of the departments and the general framework is given in Table 4 together with frequencies.

The themes that emerged from the analysis of the obtained data were in the form of job finding anxiety, career making and self-improvement desire, necessity and desire to perform teaching profession.

63 of the teacher candidates have attributed the reasons for getting education to job finding anxiety, 191 to desire to perform teaching profession for various sub-reasons, and 9 to necessity.

$18(28.57 \%)$ of those taking education due to job finding anxiety are from the department of biology, 13 (20.63\%) from the department of chemistry, 12 (19.64\%) from the department of sociology, 7 (11.11\%) from the department of food engineering, $6(9.52 \%)$ from the department of history, $4(6.35 \%)$ from the department of mathematics and $3(4.76 \%)$ from the department of physics. None of the students from midwifery-nursing department reasoned the education they took to this. 
Table 4. Themes-Categories and Frequencies Based on Departments Related to Reasons of Taking Pedagogical Formation Education

\begin{tabular}{|c|c|c|c|c|c|c|c|c|c|}
\hline Themes & & & & Departn & & & & & Total \\
\hline Categories & $\begin{array}{c}\text { Mathematics } \\
(n=47)\end{array}$ & $\begin{array}{c}\text { Midwifery-Nursing } \\
(\mathrm{n}=43) \\
\end{array}$ & $\begin{array}{l}\text { History } \\
(\mathrm{n}=\mathbf{4 1}) \\
\end{array}$ & $\begin{array}{l}\text { Biology } \\
(\mathrm{n}=\mathbf{3 0})\end{array}$ & $\begin{array}{r}\text { Chemistry } \\
(\mathbf{n}=\mathbf{3 0})\end{array}$ & $\begin{array}{r}\text { Sociology } \\
(\mathbf{n}=\mathbf{3 0})\end{array}$ & $\begin{array}{c}\begin{array}{c}\text { Food } \\
\text { Engineering }\end{array} \\
(\mathbf{n}=13) \\
\end{array}$ & $\begin{array}{r}\text { Physics } \\
(\mathrm{n}=9)\end{array}$ & \\
\hline Job finding anxiety & 4 & 0 & 6 & 18 & 13 & 12 & 7 & 3 & 63 \\
\hline Desire of career making & 0 & 7 & 3 & 2 & 2 & 5 & 0 & 2 & 21 \\
\hline $\begin{array}{l}\text { Desire to perform teaching profess } \\
\text { Idealism } \\
\text { Suitable working conditions }\end{array}$ & 25 & 13 & 21 & 9 & 8 & 5 & 3 & 4 & 88 \\
\hline Suitable profession for females & 3 & 4 & 1 & 1 & 3 & 0 & 0 & 0 & 12 \\
\hline Ease of working conditions & 0 & 26 & 1 & 4 & 4 & 0 & 2 & 0 & 37 \\
\hline Additional advantage & 8 & 1 & 1 & 2 & 2 & 6 & 3 & 0 & 23 \\
\hline Document requirement & 13 & 0 & 7 & 2 & 2 & 4 & 0 & 3 & 31 \\
\hline $\begin{array}{l}\text { Necessity } \\
\text { Family pressure }\end{array}$ & 0 & 0 & 3 & 2 & 1 & 2 & 1 & 0 & 9 \\
\hline
\end{tabular}


Below are sample excerpts from explanations of teacher candidates (TC). The departments of the teacher candidates are shortened by the initials of the departments.

"The only reason I want to get a formation is that biologists have very limited opportunities to be employed" (TC1-B).

"We have employment opportunities in our department but there are no assignments" (TC178-S)

"I wanted to take formation for assignment and employment" (TC230-H).

"The first reason for taking formation is the low level of being able to find a job in the market of my field" (TC77-P).

"Obviously it is difficult to be a state-assigned teacher without getting the formation" (TC156-M).

"It is unclear when and what will happen in this country... The purpose of taking formation for me is completely future anxiety" (TC121-C).

"I do not take it because I want to be a teacher. I could've written Faculty of Education in the university examination. I want to work in the state. I do not want to work in the factory. But assignments and KPSS (Turkish Public Personnel Selection Examination). Both the assignment score is high and they open a quota of maximum 10 people. I went with teaching despite loving my department (TC90-F).

In the study, 21 teacher candidates reasoning for taking the education to the making a career, $7(33.33 \%)$ are from of midwifery-nursing department, $5(23,809 \%)$ are from sociology department, $3(14,285 \%)$ are from history department, $2(9,523 \%)$ are from biology department and $2(9,523 \%)$ are from physics and chemistry department. There were no one from the teacher candidates of food engineering and mathematics departments who reasoned taking formation for making a career.

Some of the explanations of the teacher candidates that reasoning taking pedagogical education to the making a career and self-development are as follows:

"First of all, I am a mother. I participated in this program because I wanted to be educated about how to assess both my child and my children when I became a teacher, their behavior and attitudes" (TC107-C).

"I will add value to my life with formation, and I will develop myself in a different field. It's not a program I took just to have a career "(TC44-MW).

"My main goal is to add the teacher identity to the researcher identity as I aim to progress academically in my area. Thus I am aim to be knowledgeable in transfer what I know to the other side, be conscious" (TC77-P).

"I also graduated from social services department. I wanted to get this certificate because I want to work with both children and women "(TC212-H).

"I want to be an academician. I think that I should have formation in order to be able to give good lectures. This does not only apply to business life. It is necessary to be a good individual, a good mother, a good sociologist, a good psychologist "(TC181-S).

"I applied to improve myself" (TC13-B).

There are different categories of participants who reasoned taking formation to desire to perform teaching profession. Of these 88 teacher candidates who had the performing their dream job or in other words, idealism, underlying this desire, 88 of the teacher candidates 25 $(28,409 \%)$ were from mathematics department, 21 $(23,863 \%)$ were from history department, $13(14,772 \%)$ were from midwifery and nursing department, 9 $(10,227 \%), 8(9,090 \%)$ were from chemistry department, $5(5,681 \%), 4(4,545 \%)$ were from physics department and $3(3,409 \%)$ were from food engineering department.

Examples of the thoughts of participants are as follows:

"I wanted to be a good teacher. I wanted to be useful to children or young people. I wanted to take formation education to learn how to approach the students and how to teach them. This country needs good teachers "(TC194-S).

"The reason for taking pedagogical formation is because I really want to be a teacher. It makes me happy to realize this dream at this age (39). It is my joy to be able to learn and teach our history "(TC211-H).

"I want to be a teacher. I am a person who aimed to become a teacher since childhood. I like being with young people. I believe I will be productive "(TC75-P).

"I decided to take formation education when I noticed that I was happier teaching some things to people during my work life. I support the upbringing of newly-trained individuals in accordance with the rules, meaningful and fully equipped. Mine is not a necessity; it is all to act in the direction of my desires and purposes "(TC35-MW).

"The department I wanted to enter was mathematics teaching. However, when I couldn't enter, I thought I could at least take formation education. In other words, I am taking formation education to fulfill my dreams "(TC153-M).

"I wanted to get a formation because I like teaching. Being a teacher was my dream since childhood"(TC93-C).

"I do not want to work as an engineer. When I realize this, I ask myself what I want to do... When I looked, I saw that teaching is the right profession for me (TC86-F).

"I started working in the lab in a hospital when I graduated from university. I worked in a hospital for about 9 years, but I was not happy at all. Because I love to talk, because I have good relationships with people and because I always wanted to be a teacher, I wanted to take formation and try my luck "(TC20-B).

Teacher candidates who explained the reason for taking formation education as desire to perform teaching profession, 12 of them reasoned as thinking this a suitable profession for females and 37 as thinking that the working conditions are easy. Of the participants who took this education because they thought teaching is a suitable profession for females, 4 (\% 33,33) were from midwifery-nursing department, $3 \quad\left(\begin{array}{lll}\% & 25\end{array}\right)$ from 
mathematics department, $3(25 \%)$ from chemistry department, $1(\%$ 8,33) from Biology department and 1 $(8.33 \%)$ from history department. There are no participants in this category from other departments (physics, food engineering, sociology).

Some of the explanations of the participants who want to take the education for being a suitable profession for females are as follows:

"I decided to take formation to live a calmer life as I wanted to teach and it is seen as a profession suitable for a woman" (TC16-B).

"Performing the chemistry profession in Turkey is difficult for a woman. And as a woman I think it would be better for me to choose the teaching profession "(TC111-C).

"Teaching was already the profession I had in mind. I won the department of mathematics and an opportunity was presented. So I decided to take formation education to perform the profession that I wanted, and I also think that as a woman teaching is the most beautiful and most comfortable profession "(TC154-M).

"As a woman, I did not want to have a job with shifts. I wanted to raise my children at home in the night "(TC49-MW).

"When we look at the profession, it is an ideal profession for women. I must say that teaching is a skill that comes from within you "(TC201-H).

Of the teacher candidates who desire to perform teaching profession because they think working conditions are easy, $26(70,27 \%)$ are from midwifery-nursing department, 4 (\% 10,81) from biology department, 4 $(10,81 \%)$ from chemistry department, 2 (5,405\%) from food engineering department and $1(2.702 \%)$ from history department. There are no participants in this category from other departments (physics, mathematics, sociology).

For this reason, examples of thoughts of participants about formation education are as follows:

"I worked as a chemist in the mining industry in the laboratory for 5 years. I left my job 1 year ago and got married. Since my spouse is a police officer, I thought it would be better for me to be a teacher because of east duty, and I decided to take the formation "(TC106-C).

"I love the food engineering department I am studying, but I chose to work in the state because of the heavy working conditions in the private sector and the inability to pay the necessary compensation. In the State, the number of recruitment is small and the scores are very high, so I would like to be a teacher "(TC81-F).

"I am very tired of the job I am working now; I am very exhausted. I have been working as a nurse for 15 years in public. After getting married and had children, it is very difficult to keep shifts, be separated from my child for 24 hours. I decided to continue studying to change the department. I am studying biology. Either I will change my title in the hospital and stay as a biologist or switch to teacher with formation. The reason for taking formation is that I do not want to change jobs"(TC11-B).

"I cannot say that I chose my department very willingly. The only attractive part was to ease of employment. I've been doing this for a year and a half. I'm really tired. Neither the sleeping pattern nor the social life, nor the psychological state of the person is proper, nor does the compensation of the labor is good. That's why I want the formation. I will become a teacher"(TC22-MW).

Of the participants who came with the desire to perform teaching profession, those who link their reasons to desire to have an additional advantage (living conditions), 23 $(34,782 \%)$ were from mathematics department, 6 (26,086\%) from sociology department, 3 (13,043\%) from food engineering department, 2 (23\%) from biology department, $2(8,695 \%)$ from chemistry department, 1 $(4,347 \%)$ midwifery-nursing department and $1(4,347 \%)$ from history department. There are no participants in this category from the physics department. Given below are the examples of participants:

"I am not taking formation because I will surely be a teacher. I just used the right given (TC129-M).

"I am taking formation to expand the variety in the sense of profession" (TC6-B).

"I am taking the formation because I think it will be an alternative profession at hand" (TC84-F).

"I wanted to take the formation as a second degree, a second chance for business life" (TC120-C).

"Because the recruitment for sociologists are low and there are not many fields in the private sector. I am also taking it to increase the likelihood of being a government officer as a teaching certificate "(TC174-S).

"Although I aimed to progress in the department, I wanted to take the formation as an opportunity for teaching, another profession that I like. I think of teaching as an additional profession "(TC208-H).

Of the teacher candidates, those who link their reasons of taking formation to desire to perform teaching profession and seeing the certificate obtained as fulfilling document requirement, $31 \quad(41,935 \%)$ were from mathematics department, $7 \quad(22,58 \%)$ from history department, $4(12,903 \%)$ from sociology department, 3 $(9,677 \%)$ from physics department, 2 (6,451\%) from chemistry department and $2(6,451 \%)$ from biology department. In this category there are no participants from midwifery-nursing and food engineering. For this reason, examples of thoughts of participants taking formation education are as follows:

"I used to work at a training center. We are out of working areas when the training centers are shut down. Now, I decided to take formation to be able to work in private schools "(TC235-H).

"I had to take a formation to work as a guidance counsellor in a private educational institution. So I participated in this training "(TC171-S).

"I quit my job to get this education. I was offered institution management where I was working. However, 
because I didn't have formation certificate, I wasn't assigned for 4 years. I wanted to take this certificate because I think it will always be an obstacle for me "(TC72-P).

"I receive formation education because government closes training centers and encourages opening colleges, and because the colleges require the certificated called formation" (TC117-C). "I had to legalize teaching which was at the center of my life for many years. For this reason, I wanted to take formation"(TC24-B).

"I work in the prison as an execution and protection officer. There is a unit in the institution, called prison teacher. If I get this certificate, I want to change my unit next year and become a prison teacher "(TC130-M).

9 of the teacher candidates have attributed their reasons for taking this education to necessity due to family pressure. Of the teacher candidates who think like this, 3 $(33.33 \%)$ are from history department, 2 (22.22\%) are from sociology department, $2(22.22 \%)$ are from biology department, $1(11.11 \%)$ is from chemistry department and $1(11,11 \%)$ is from food engineering department. There are no other participants from other departments (midwifery-nursing, physics and mathematics) that think this way. For this reason, examples of thoughts of participants taking formation education are as follows:

"I took it to make my family happy who insisted on the formation" (TC28-B).

"I take it because my family wants it" (TC87-F).

The reason for taking formation was my father. I took because of his pressure "(TC97-C).

"I was not very willing. My family wanted it"(TC97-S).

"I never wanted. I had to take it because of my brother's pressure and financial support "(TC226-H).

\section{Discussion and Conclusion}

Nowadays, teaching profession is considered as a professional occupation which has its own principles, methods and practices; which requires professional qualifications such as academic work, professional formation, expertise knowledge and skill in the field, as well as personal features including a contemporary worldview on social, cultural, economic, scientific and technological dimensions [52-54].

In the study, the reasons for the education of the teacher candidates from eight different departments receiving pedagogical formation training were researched and their thoughts were analyzed by qualitative research methods. When the data obtained from the research are examined, it was seen that the reasons generally appear as "job finding anxiety, career making and self-development desire, necessity and desire to perform teaching profession".

Most of those with the reason of job finding anxiety are from biology and sociology department, and the least from midwifery-nursing department, most of those with the reason for career making and self-development are from midwifery-nursing department and the least from physics and chemistry department.

As a matter of fact, some research suggests that occupational choices are predominantly based on economic factors, thus differentiating the occupational preferences of people from their actual needs [21,25]. The situation is not different for the teaching profession, because the research made $[20,22,55]$ points attention to the role of extrinsic factors in preferring the teaching profession.

It was seen that most of the participants who considered education as a necessity were mostly from history department and least from the physics, mathematics and midwifery-nursing departments, and they attributed this to family pressure. It was seen that most of those coming with the desire to perform teaching profession, those reasoning to perform their dream job are from mathematics and history departments and least from the food-engineering department; Most of those reasoning to desire to gain an additional advantage are from the mathematics department and least from the physics department; Most of those reasoning with meeting requisite certificate need are from mathematics department and least from food engineering and midwifery-nursing department.

In addition, it was seen that from those who want to perform teaching profession because they think that professional conditions are appropriate, those reasoning as being a suitable profession for women are mostly from of midwifery-nursing departments, least from physics, food and sociology departments, and those reasoning as working conditions being easy are mostly from midwifery-nursing department and least from physics, mathematics and sociology departments. As a matter of fact, the perception of teaching as a profession for women and its preference more by women have been expressed in many studies [56-58]. In many studies abroad, especially in the UK, this has been referred to as the "feminization" of the profession [59]. Similar results in some studies conducted in our county $[31,60]$ are noteworthy.

It is generally seen that the main reason for the participants to take this education is to perform teaching profession. When this reason is examined, the fact that the first underlying factor is performing the dream profession with an idealistic thought is parallel to some studies on the reasons of choosing the teaching profession that was done before [33,61-64]. The fact that most of the candidate teachers who took formation education due to thinking it is suitable for women or working conditions are easy being from midwifery-nursing department, and considering these candidates are also working, it can be evaluated as a different result in terms of drawing attention to the importance of the qualifications and the outlook of those to perform this profession on the profession. In addition, when considering the outlooks on the profession of these who took this education with regard to job-finding anxiety, 
being employed in a short time being the main priority in choosing a profession [13], which is related to the individuals' sustaining their profession in a satisfactory manner throughout life; suggests that variables such as personality, interest, and talent are not considered sufficiently [14]. As an added advantage, the need to meet a certificate requirement, or the consequences of taking this education due to family pressure reiterates a similar idea.

In conclusion, it is suggested that those who see the teaching profession as their ideal profession and those who do careers and take pedagogical formation to develop themselves are teachers who are willing to practice profession in a meaningful way. However, anxiety about job finding, thinking that working conditions are easy, meeting the need for required certificates in private institutions, or other causes such as family pressure, loses the meaning of pedagogical formation and the outlook of the future teacher candidates on the profession and their required qualifications seem troubling.

In the preference of teaching profession, the expectations of the individual about the teaching profession, the outlook on the profession and the values of the teaching profession are important [12]. As a matter of fact, the profession of teaching is a profession which should be chosen consciously, and social responsibility is carried at a high level. Therefore, it is considered important that this profession be performed by teacher candidates who come to education faculties, or if proficiency will be given with pedagogic formation, it is important to take the necessary precautions to give this education to those who have the qualifications and the outlook required by the profession in selecting candidates.

\section{Note}

A part of this study was presented at the $3^{\text {rd }}$ International Dynamic, Explorative and Active Learning (IDEAL) Conference as an oral presentation.

\section{REFERENCES}

[1] Aysu, B. (2007). Okul öncesi öğretmen adaylarının öğretmenlik mesleğine karşı tutumlarının incelenmesi. Ankara Üniversitesi Fen Bilimleri Enstitüsü, Yüksek Lisans Tezi, Ankara.

[2] Çevik, O. \& Yiğit, S. (2009). Eğitim fakültesi öğrencilerinin profillerinin belirlenmesi: Amasya Üniversitesi örneği. Cumhuriyet Üniversitesi Sosyal Bilimler Dergisi, 33(1), 89-106.

[3] Yanıkkerem, E., Altınparmak, S. \& Karadeniz, G. (2004). Gençlerin meslek seçimini etkileyen faktörler ve benlik saygılar1. Nursing Forum Dergisi, 7(2),61- 62.

[4] Kuzgun, Y. (2000). Meslek Danışmanlı̆̆ (2. Ed) Ankara:
Doğuş Matbaacılık.

[5] Bozdoğan, A. E., Aydın, D. \& Yıldırım, K. (2007) Öğretmen adaylarının öğretmenlik mesleğine ilişkin tutumları. Ahi Evran Üniversitesi Kırşehir Eğitim Fakültesi Dergisi, 8(2), 83-97.

[6] Akyüz, Y. (2007). Türk Eğitim Tarihi. Ankara: Pegem A Yayınc1lik

[7] Çetin, Ş. (2006). Öğretmenlik mesleği tutum ölçeğinin geliştirilmesi (geçerlik ve güvenirlik çalışması). Gazi Üniversitesi Endüstriyel Sanatlar Eğitim Fakültesi Dergisi, $18,28-37$.

[8] Bircan, İ. (2005). Öğretmenlik mesleğinin geleceği ve istihdam sorunu. Eğitim Fakültelerinde Yeniden Yapılandırmanın Sonuçları ve Öğretmen Yetiştirme Sempozyumu, 22-24 Eylül 2005, Gazi Üniversitesi, Ankara.

[9] YÖK (1998). Fakülte Okul İşbirliği. YÖK/Dünya Bankası Milli Eğitimi Geliştirme Projesi Hizmet Öncesi Öğretmen Eğitimi, Ankara.

[10] MEB, (2006). Öğretmenlik Mesleği Genel Yeterlikleri. http://otmg.meb.gov.tr/YetGenel.html

[11] Helvacı, M. A. (2009). Öğretmenlik Mesleğinin Özellikleri, (Ed. N. Saylan) Eğitim Bilimine Giriş, Anı Yayıncılık: Ankara

[12] Akbaba, S. (2002). Öğretmen yetiştirmede mesleki rehberliğin yeri ve önemi. Milli Eğitim Dergisi, 155-156, 21-31.

[13] Çeliköz, N. (2004). Anadolu öğretmen lisesi öğrencilerinin öğretmenlik mesleğine yönelik tutumlarını etkileyen etmenler. Milli Eğitim Dergisi, 32, 136-145.

[14] Yazıc1, H. (2009). Öğretmenlik mesleği, motivasyon kaynakları ve temel tutumlar: Kuramsal bir bakış. Kastamonu Eğitim Dergisi, 17(1), 33-46.

[15] Goddard, R. \& O'brien, P. (2003). Beginning Teachers' Perceptions of Their Work, Well-Being and Intention to Leave, Asia-Pacific Journal of Teacher Education and Development, 6(2), 99-118.

[16] Kyriacou, C. \& Coulthard, M. (2000). Undergraduates' views of teaching as acareer choice. Journal of Education for Teaching, 26,117-126. http://dx.doi.org/10.1080/02607470050127036

[17] Kyriacou, C. \& Kunc, R. (2007). Beginning Teachers' Expectations of Teaching, Teaching and Teacher Education, 23, 1246-1257.

[18] Manuel, J. \& Hughes, J. (2006). It Has Always Been My Dream':Exploring Pre-Service Teachers' Motivations for Choosing to Teach, Teacher Development, 10(1), 5-24.

[19] Smithers, A. \& Robinson, P. (2003). Factors Affecting Teachers' Decisions to Leave the Profession. Department For Education And Skills: London

[20] Bastick, T. (2000). Why teacher trainees choose the teaching profession? Comparing trainees in metropolitan and developing countries. International Review of Education, 46(3/4),343-349.

http://dx.doi.org/10.1023/A:1004090415953 
[21] Behymer, J. \& Cockriel, I. W. (1988). Career choice conflict. Journal of Career Development, 15(2), 134-140.

[22] Boz, Y. \& Boz, N.(2008). Kimya ve Matematik Öğretmen Adaylarının Öğretmen Olma Nedenleri. Kastamonu Eğitim Dergisi, 16(1), 137-144.

[23] Brown, M. M. (1992) Caribbean first-year teachers' reasons for choosing teaching as a career. Journal of Education for Teaching,18(2),185-195. http://dx.doi.org/10.1080/0260747920180207

[24] Chuene K, Lubben F \& Newson G (1999) The views of pre-service and noviceteachers on mathematics teaching in South Africa related to their educational experience. EducationalResearch,41(1),23-34. http://dx.doi.org/10.1080/0013188990410103

[25] Kniveton, B. H. (2004). The influences and motivations on which students base their choice of career. Research in Education,72,47-57. http://dx.doi.org/10.7227/RIE.72.4

[26] Kyriacou, C. \& Newson, G. (1998). Undergraduates' views of teaching mathematics in a secondary school as a career. Curriculum 19, 61-64.

[27] Kyriacou, C. Haltgreen, A. \& Stephens, P. (1999). Student teachers' motivation to become a secondary school teacher in England and Norway, Teacher Development, 3(3), 373381 .

[28] Moran, A., Kilpatrick, R., Abbott, L., Dallat, J., \& McClune, B. (2001) Training to teach: Motivating factors and implications for recruitment. Evaluation and Research in Education 15, 17-32.

[29] Papanastasiou, C. \& Papanastasiou, E. (1997). Factors that influence students to become teachers. Educational Research and Evaluation 3(4),305-316. http://dx.doi.org/10.1080/1380361970030402

[30] Reid I. \& Caudwell J. (1997) Why did secondary PGCE students choose teaching as a career? Research in Education, 58(1), 46-58.

[31] Şaban, A. (2003). A Turkish profile of prospective elementary school teachers and their views of teaching. Teaching and Teacher Education, 19, 829-846.

[32] Spear M, Gould K \& Lee B (2000) Who would be a teacher? A review of factors motivating and demotivating prospective and practising teachers. Slough: National Foundation for Educational Research.

[33] Yong, B.C.S. (1995) Teacher Trainees' Motives for Entering into a Teaching Career in Brunei Darussalam, Teaching and Teacher Education, 11, 275-280.

[34] Clutter, C. (2010). The Effects of Parental İnfluence on Their Children's Career Choices. Unpublished master thesis. Kansas State University, Manhattan.

[35] Edwards, K. ve Quinter, M. (2011). Factors Influencing Students Career Choices Among Secondary School Students in Kisumu Municipality, Kenya. Journal of Emerging Trends in Educational Research and Policy Studies. 2(2), 81-87.

[36] Ubuz, B. \& Sarı, S. (2008). Sınıf Öğretmeni Adaylarının Öğretmenlik Mesleğini Seçme Nedenleri. Pamukkale Üniversitesi Eğitim Fakültesi Dergisi, 24(2), 113-119
[37] Cermik, H., Doğan, B. \& Sahin, A. (2010). Sınıf Öğretmenliği Öğretmen Adaylarının Öğretmenlik Mesleğini Tercih Sebepleri. Pamukkale Üniversitesi Eğitim Fakültesi Dergisi, 28,201-212.

[38] Kaya, E. \& Yıldırım, T. (2015). Fen fakültesi biyoloji bölümü öğrencilerinin gözüyle öğretmenlik. Bayburt Üniversitesi Eğitim Fakültesi Dergisi. 10(2), 375-384.

[39] Kavcar C. (2002). Cumhuriyet döneminde dal öğretmeni yetiştirme. Ankara Üniversitesi Eğitim Bilimleri Fakültesi Dergisi, 35 (1-2), 1-14.

[40] Eraslan, L. \& Çakıcı, D. (2011). Pedagojik formasyon programı öğrencilerinin öğretmenlik mesleğine yönelik tutumları. Kastamonu Eğitim Dergisi. 19(2), 427-438.

[41] Polat, S. (2014). Bir mesleğe/işe sahip olan pedagojik formasyon eğitimi sertifika programı öğrencilerinin öğretmenlik mesleğine yönelme nedenleri. International Journal of Human Sciences, 11(1),128-144.

[42] Kartal, T. \& Afacan, Ö. (2012). Pedagojik formasyon eğitimi alan öğretmen adaylarının öğretmenlik mesleğine ilişkin tutumlarının incelenmesi. Mehmet Akif Ersoy Üniversitesi Eğitim Fakültesi Dergisi, 24, 76 - 96.

[43] Özkan, H. H. (2012). Öğretmenlik formasyon programındaki öğretmen adaylarının öğretmenlik mesleğine ilişkin tutumlarının incelenmesi. Ahi Evran Üniversitesi Kırşehir Eğitim Fakültesi Dergisi, 13(2), $29-48$.

[44] Polat, S. (2013). Pedagojik formasyon sertifika programı ve eğitim fakültesi öğrencilerinin öğretmenlik mesleğine yönelik tutumlarının incelenmesi. E-International Journal of Educational Research, 4(2), 48-60.

[45] Demircioğlu, E. \& Özdemir, M. (2014). Pedagojik formasyon öğrencilerinin çok kültürlü eğitime yönelik tutumlarının bazı değişkenlere göre incelenmesi. Ege Eğitim Dergisi, (15)1, 211-232.

[46] Altınkurt, Y., Yılmaz, K \& Erol, E. ( 2014). Pedagojik Formasyon Programı Öğrencilerinin Öğretmenlik Mesleğine Yönelik Motivasyonları. Trakya Üniversitesi Eğitim Fakültesi Dergisi. 4(1), 48-62.

[47] Kiraz, Z. \& Dursun, F. (2015). Pedagojik Formasyon Eğitimi Alan Öğretmen Adaylarının Aldıkları Eğitime İlişkin Algıları. Mersin Üniversitesi Eğitim Fakültesi Dergisi, 11(3),1008-1028.

[48] Yıldırım A. \& Şimşek H. (2005). Sosyal Bilimlerde Nitel Araştırma Yöntemleri. Ankara: Seçkin Yayıncılık

[49] Yin, R.K. (2003). Case Study Researches, Design and Methods. California: Sage Publications.

[50] Creswell, J. W. (2008). Educational Research: Planning, conducting, and evaluating quantitative and qualitative research. (3rd Ed.). Pearson Education, Inc.

[51] Lincoln, Y. S. \& Guba, E.G. (1985). Naturalistic inquiry. Newburry Park, CA: Sage.

[52] Erden, M. (1999). Öğretmenlik mesleğine giriş. İstanbul: Alkım Yayıncılık

[53] YÖK. (1998a). Eğitim fakülteleri öğretmen yetiştirme programlarının yeniden düzenlenmesi. Ankara: T.C. 
Yüksek Öğretim Kurulu Başkanlığı.

[54] YÖK. (1998b). Eğitim fakültesi öğretmen yetiştirme lisans programları. Ankara: T.C. Yüksek Öğretim Kurulu Başkanlığı.

[55] Papanastasiou, C., \& Papanastasiou, E. (1998). What influences students to choose the elementary education major: The case of Cyprus. Mediterranean Journal of Educational Studies, 3, 35-45.

[56] Foster, T. \& Newman, E. (2005). Just a knock back? Identity bruising on their route to becoming a male primary school teacher. Teachers and Teaching: Theory and Practice, 11(4), 341-358.

[57] Johnston, J., McKeown, E. \& McEwen, A. (1999). Choosing primary teaching as a career: The perspectives of males and females in training. Journal of Education for Teaching, 25(1), 55-64.

[58] Smedley, S. (2007). Learning to be a primary school teacher: reading one man's story. Gender and Education, 19(3), 369-385.

[59] Parr, M., Gosse, Douglas, \& Allison, J. (2008). The professional journey of male primary teachers:
Experiences and perceptions of entering into a sacred female space. The International Journal of Diversity in Organisations, Communities and Nations, 7(6), 257-265.

[60] Şahin, A., Çokadar, H. \& Uşak, M. (2008). Context, process and change: The status of prospective teachers' perception of teaching process. Essays in Education, 23, 129-141.

[61] Okçabol, R. (2004). Türkiye'de öğretmen profili araştırması ve öğretmen yetiştirmede yeni arayışlar. İstanbul: Boğaziçi Üniversitesi Yayınları.

[62] Övet, O. (2006). Eğitim fakültesi öğrencilerinin öğretmenlik mesleğini tercih etmelerinde etkili olan faktörlerin belirlenmesi. Yüksek Lisans Tezi. İstanbul: Yeditepe Üniversitesi Sosyal Bilimler Enstitüsü.

[63] Serow, R. C., Eaker, D. \& Ciechalski, J. (1992). Calling, service and legitimacy: Professional orientations and career commitment among prospective teachers. Journal of Research and Development in Education, 25(3), 136-141.

[64] Özsoy G., Özsoy, S., Özkara, Y. \& Memiş, A. D. (2010). Öğretmen adaylarının öğretmenlik mesleğini tercih etmelerinde etkili olan faktörler. Elementary Education Online, 9(3), 910-921. 